Table 1. TEAEs and Key Safety Outcomes Week 0-24 by Age Group, $\mathrm{n}(\%)$

\begin{tabular}{lcccccc}
\hline & \multicolumn{3}{c}{$<65$ yrs $(\mathrm{n}=335)$} & \multicolumn{3}{c}{$\geq 65$ yrs $(\mathrm{n}=113)$} \\
\hline Regimen & $\begin{array}{c}\text { FIL 200 } \\
(\mathrm{n}=112)\end{array}$ & $\begin{array}{c}\text { FIL 100 } \\
(\mathrm{n}=117)\end{array}$ & $\begin{array}{c}\text { PBO } \\
(\mathrm{n}=106)\end{array}$ & $\begin{array}{c}\text { FIL 200 } \\
(\mathrm{n}=35)\end{array}$ & $\begin{array}{c}\text { FIL 100 } \\
(\mathrm{n}=36)\end{array}$ & $\begin{array}{c}\text { PBO } \\
(\mathrm{n}=42)\end{array}$ \\
\hline TEAE & 72 & 81 & 70 & 30 & 16 & 30 \\
& $(64.3)$ & $(69.2 \%)$ & $(66.0 \%)$ & $(85.7 \%)$ & $(44.4 \%)$ & $(71.4 \%)$ \\
Serious AE & $4(3.6)$ & $7(6.0 \%)$ & $4(3.8 \%)$ & $2(5.7 \%)$ & $1(2.8 \%)$ & $1(2.4 \%)$ \\
TEAE leading to study drug & $4(3.6)$ & $6(5.1 \%)$ & $1(0.9 \%)$ & $1(2.9 \%)$ & 0 & $2(4.8 \%)$ \\
discontinuation & & & & & & \\
Infection & 39 & 47 & 27 & 14 & 5 & 11 \\
& $(34.8)$ & $(40.2 \%)$ & $(25.5 \%)$ & $(40.0 \%)$ & $(13.9 \%)$ & $(26.2 \%)$ \\
Herpes Zoster & $2(1.8)$ & $2(1.7)$ & 0 & 0 & 0 & 0 \\
(uncomplicated) & & & & & & \\
Serious infection & $1(0.9)$ & $3(2.6)$ & $2(1.9)$ & 0 & 0 & 0 \\
MACE & 0 & $1(0.9)$ & $1(0.9)$ & 0 & 0 & 0 \\
Retinal vein occlusion & $1(0.9)$ & 0 & 0 & 0 & 0 & 0 \\
\hline
\end{tabular}

Table 2. Week 24 Key Efficacy Measures by Age Group

\begin{tabular}{lcccccc}
\hline & \multicolumn{3}{c}{$<65$ yrs $(\mathrm{n}=335)$} & \multicolumn{3}{c}{$\geq 65$ yrs $(\mathrm{n}=113)$} \\
\hline Regimen & $\begin{array}{l}\text { FIL 200 } \\
(\mathrm{n}=112)\end{array}$ & $\begin{array}{c}\text { FIL 100 } \\
(\mathrm{n}=117)\end{array}$ & $\begin{array}{c}\text { PBO } \\
(\mathrm{n}=106)\end{array}$ & $\begin{array}{c}\text { FIL 200 } \\
(\mathrm{n}=35)\end{array}$ & $\begin{array}{c}\text { FIL 100 } \\
(\mathrm{n}=36)\end{array}$ & $\begin{array}{c}\text { PBO } \\
(\mathrm{n}=42)\end{array}$ \\
\hline ACR20 $\mathrm{n}(\%)^{1}$ & $78(70) \dagger$ & $60(51) \dagger$ & $33(31)$ & $24(69)^{*}$ & $24(67)^{*}$ & $18(43)$ \\
DAS28(CRP)<2.6 $\mathrm{n}$ & $33(30) \ddagger$ & $26(22)^{*}$ & $11(10)$ & $12(34)$ & $14(39)^{*}$ & $7(17)$ \\
$(\%)^{1}$ & & & & & & \\
HAQ-DI mean CFB & -0.75 & -0.60 & -0.40 & -0.74 & -0.59 & -0.48 \\
$(\mathrm{SD})$ & $(0.66) \dagger$ & $(0.66)^{*}$ & $(0.58)$ & $(0.48)^{*}$ & $(0.67)$ & $(0.65)$ \\
SF-36 PCS mean CFB & $9.4(8.6) \dagger$ & $9.2(8.7) \dagger$ & $6.2(8.2)$ & $9.4(6.7)^{*}$ & $8.5(7.8)$ & $7.5(7.4)$ \\
(SD) & & & & & & \\
FACIT-Fatigue mean & 11.2 & 9.6 & 7.2 & 12.9 & 10.3 & 6.4 \\
CFB (SD) & $(11.6) \dagger$ & $(11.1)$ & $(10.1)$ & $(12.2)^{*}$ & $(8.3)$ & $(10.7)$ \\
\hline
\end{tabular}

${ }^{*} \mathrm{p}<0.05,{ }^{\dagger} \mathrm{p}<0.01, \$ \mathrm{p}<0.001 \mathrm{CFB}$, change from BL. ${ }^{1}$ Nonresponder imputation

Disclosure of Interests: Kenneth Kalunian Grant/research support from: Gilead Sciences, Inc., Jacques-Eric Gottenberg Grant/research support from: Bristol-Myers Squibb, Grant/research support from: Bristol-Myers Squibb, Consultant for: Bristol-Myers Squibb, Lilly, Pfizer, Sanofi-Genzyme, UCB Pharma, Consultant for: Bristol-Myers Squibb, Eli Lilly, UCB, SanofiGenzyme, Pfizer, Mark C. Genovese Grant/research support from: Sanofi/ Genzyme, Genentech/Roche, RPharm, Consultant for: Sanofi/Genzyme, Genentech/Roche, RPharm, Neelufar Mozaffarian Shareholder of: Gilead, Employee of: Gilead, Beatrix Bartok Shareholder of: Gilead, Employee of: Gilead, Franziska Matzkies Shareholder of: Gilead, Employee of: Gilead, Jie Gao Shareholder of: Gilead, Employee of: Gilead, Ying Guo Shareholder of: Gilead, Employee of: Gilead, Tsutomu Takeuchi Grant/research support from: Astellas Pharma Inc, Chugai Pharmaceutical Co, Ltd., Daiichi Sankyo Co., Ltd., Takeda Pharmaceutical Co., Ltd., AbbVie GK, Asahikasei Pharma Corp., Mitsubishi Tanabe Pharma Co., Pfizer Japan Inc., Eisai Co., Ltd., AYUMI Pharmaceutical Corporation, Nipponkayaku Co. Ltd., Novartis Pharma K.K., Grant/research support from: AbbVie, Asahi Kasei, Astellas, AstraZeneca, AYUMI, Bristol-Myers Squibb, Chugai, Daiichi Sankyo, Eisai, Eli Lilly Japan, Janssen, Mitsubishi Tanabe, Nippon Kayaku, Novartis, Pfizer Japan Inc, Taiho, Taisho Toyama, Takeda, Teijin, Grant/research support from: Astellas Pharma Inc., Bristol Myers Squibb, Chugai Pharmaceutical Co., Ltd., Mitsubishi Tanabe Pharma Co., Pfizer Japan Inc., Santen Pharmaceutical Co., Ltd., Takeda Pharmaceutical Co., Ltd., Teijin Pharma Ltd., AbbVie GK, Asahi Kasei Pharma Corp., Taisho Toyama Pharmaceutical Co., Ltd., SymBio Pharmaceuticals Ltd., Janssen Pharmaceutical K.K., Celltrion Inc., Nipponkayaku Co. Ltd., and UCB Japan, Consultant for: Astra Zeneca K.K., Eli Lilly Japan K.K., Novartis Pharma K.K., Mitsubishi Tanabe Pharma Co., Abbivie GK, Nipponkayaku Co.Ltd, Janssen Pharmaceutical K.K., Astellas Pharma Inc., Taiho Pharmaceutical Co. Ltd., Chugai Pharmaceutical Co. Ltd., Taisho Toyama Pharmaceutical Co. Ltd., GlaxoSmithKline K.K., UCB Japan Co. Ltd., Consultant for: AbbVie, Asahi Kasei, Astellas, AstraZeneca, AYUMI, Bristol-Myers Squibb, Chugai, Daiichi Sankyo, Eisai, Eli Lilly Japan, Janssen, Mitsubishi Tanabe, Nippon Kayaku, Novartis, Pfizer Japan Inc, Taiho, Taisho Toyama, Takeda, Teijin, Consultant for: Astra Zeneca K.K., Eli Lilly Japan K.K., Novartis Pharma K.K., Mitsubishi Tanabe Pharma Co., Asahi Kasei Medical K.K., AbbVie GK, Daiichi Sankyo Co., Ltd., Bristol Myers Squibb, and Nipponkayaku Co. Ltd., Speakers bureau: Astellas Pharma Inc., Bristol Myers Squibb, Chugai Pharmaceutical Co., Ltd., Mitsubishi Tanabe Pharma Co., Pfizer Japan Inc., Santen Pharmaceutical Co., Ltd., Takeda Pharmaceutical Co., Ltd., Teijin Pharma Ltd., AbbVie GK, Asahi Kasei Pharma Corp., Taisho Toyama Pharmaceutical Co., Ltd., SymBio Pharmaceuticals Ltd., Janssen Pharmaceutical K.K., Celltrion Inc., Nipponkayaku Co. Ltd., and UCB Japan, Speakers bureau: AbbVie, Asahi Kasei, Astellas, AstraZeneca, AYUMI, Bristol-Myers Squibb, Chugai,
Daiichi Sankyo, Eisai, Eli Lilly Japan, Janssen, Mitsubishi Tanabe, Nippon Kayaku, Novartis, Pfizer Japan Inc, Taiho, Taisho Toyama, Takeda, Teijin, Speakers bureau: AbbVie GK., Bristol-Myers K.K., Chugai Pharmaceutical Co. Ltd., Mitsubishi Tanabe Pharma Co., Pfizer Japan Inc., Astellas Pharma Inc, Diaichi Sankyo Co. Ltd., Eisai Co. Ltd., Sanofi K.K., Teijin Pharma Ltd., Takeda Pharmaceutical Co. Ltd., Novartis Pharma K.K., Kurt de Vlam Consultant for: Pfizer Inc, Consultant for: Johnson \& Johnson, David Walker: None declared

DOI: 10.1136/annrheumdis-2019-eular.2121

\section{FRI0155 A COMPARISON OF UPADACITINIB PLUS METHOTREXATE AND UPADACITINIB PLUS OTHER CSDMARDS IN PATIENTS WITH RHEUMATOID ARTHRITIS: AN ANALYSIS OF TWO PHASE 3 STUDIES}

Joel Kremer ${ }^{1}$, Filip van den Bosch ${ }^{2}$, Andrea Rubbert-Roth ${ }^{3}$, Sebastião C. Radominski ${ }^{4}$, Gerd Rüdiger Burmester ${ }^{5}$, Heidi Camp ${ }^{6}$, Sebastian Meerwein ${ }^{7}$, Mark Howard ${ }^{6}$, Yanna Song ${ }^{6}$, Sheng Zhong ${ }^{6}$, Bernard Combe ${ }^{8} .{ }^{1}$ Albany Medical College, Albany, United States of America; ${ }^{2}$ Ghent University Hospital and Ghent University, Ghent, Belgium; ${ }^{3}$ Kantonsspital St Gallen, St Gallen, Switzerland; ${ }^{4}$ Universidade Federal do Paraná, Curitiba, Brazil; ${ }^{5}$ Charité-Universitätsmedizin, Berlin, Germany; ${ }^{6}$ AbbVie Inc., North Chicago, United States of America; ${ }^{7}$ AbbVie Deutschland, Ludwigshafen, Germany; ${ }^{8} \mathrm{CHU}$ Montpellier, Université de Montpellier, Montpellier, France

Background: Upadacitinib (UPA), a selective JAK1 inhibitor, has shown efficacy in patients with rheumatoid arthritis (RA) when combined with methotrexate (MTX) or other conventional synthetic disease-modifying antirheumatic drugs (csDMARDs). ${ }^{1,2}$ However, the efficacy of UPA plus MTX has not been directly compared with UPA plus other csDMARDs.

Objectives: To compare the efficacy of UPA in combination with MTX versus UPA in combination with other csDMARDs in patients with an inadequate response (IR) to csDMARDs (SELECT-NEXT ${ }^{1}$ ) or biologic DMARDs (bDMARDs; SELECT-BEYOND ${ }^{2}$ ).

Methods: 661 patients in SELECT-NEXT and 498 patients in SELECTBEYOND received UPA $15 \mathrm{mg}$ or $30 \mathrm{mg}$ once daily (QD) or placebo (PBO) for 12 weeks; all patients received concomitant $\operatorname{csDMARD(s).~The~}$ primary endpoints for both studies were rates of ACR20 response and DAS28(CRP) $\leq 3.2$. Additional endpoints included DAS28(CRP) $<2.6$, CDAl low disease activity $(\leq 10)$, and CDAI remission $(\leq 2.8)$. Patients were grouped according to concomitant csDMARD use (MTX vs non-MTX csDMARDs); patients receiving both MTX and a non-MTX csDMARD were included in the MTX group. p-values were calculated based on a logistic regression model with treatment group and type of background csDMARD as fixed factors, adjusting for demographic and baseline factors. p-values from the interaction between treatment group and background csDMARD were also calculated, to assess the consistency of the effects of study treatments for different background csDMARD type. Nonresponder imputation was used for missing data.

Results: In SELECT-NEXT and SELECT-BEYOND, 535 and 410 patients, respectively (80\%), were receiving concomitant MTX (mean dose $17 \mathrm{mg} /$ week), and 124 and 82 patients were receiving non-MTX csDMARDs. Demographics and disease characteristics were broadly similar between treatment groups; the majority of patients were female and of white ethnicity, and around half were using oral corticosteroids at baseline. Across all subgroups, the proportion of patients achieving efficacy outcomes was higher with both UPA doses compared with PBO (Table). There were no significant differences between efficacy outcomes with UPA in combination with MTX versus UPA in combination with non-MTX csDMARDs in either patient population. This included ACR20 response as well as low disease activity and remission defined by DAS28(CRP) and CDAl.

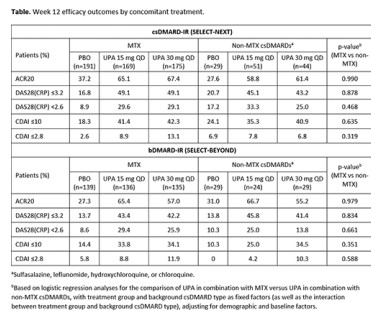

Conclusion: In this post hoc analysis, the efficacy of UPA in patients with RA appeared comparable whether administered in combination with MTX or non-MTX csDMARDs. 


\section{REFERENCES:}

[1] Burmester GR, et al. Lancet 2018;391:2503-12;

[2] Genovese MC, et al. Lancet 2018;391:2513-24

Acknowledgement: AbbVie, Inc was the study sponsor, contributed to the study design, data collection, analysis \& interpretation, and to writing reviewing, and approval of the final version. Medical writing support was provided by John Ewbank, PhD, of 2 the Nth.

Disclosure of Interests: Joel Kremer Grant/research support from: AbbVie, Genentech, Lilly, Novartis, Pfizer, Consultant for: AbbVie, Amgen, BMS Genentech, Lilly, Regeneron, Sanofi, Pfizer, Filip van den Bosch Consultant for: AbbVie, BMS, Galapagos, Janssen, Lilly, Merck, Novartis, Pfizer and UCB, Speakers bureau: AbbVie, BMS, Janssen, Lilly, Merck, Novartis, Pfizer and UCB., Andrea Rubbert-Roth Consultant for: Abbvie, Speakers bureau: AbbVie, Sebastião C. Radominski Consultant for: AbbVie, Celgene, Genentech/Roche, Janssen, Pfizer, and UCB, Paid instructor for: AbbVie, Celgene, Genentech/Roche, Janssen, Pfizer, and UCB, Speakers bureau: AbbVie, Celgene, Genentech/Roche, Janssen, Pfizer, and UCB Gerd Rüdiger Burmester Consultant for: Roche, Sanofi-Genzyme, Speakers bureau: Roche, Sanofi-Genzyme, Heidi Camp Shareholder of: AbbVie Employee of: AbbVie, Sebastian Meerwein Shareholder of: AbbVie, Employee of: AbbVie Deutschland $\mathrm{GmbH} \&$ Co. KG, Mark Howard Shareholder of: AbbVie, Employee of: AbbVie, Yanna Song Shareholder of: AbbVie, Employee of: AbbVie, Sheng Zhong Shareholder of: AbbVie, Employee of: AbbVie, Bernard Combe Consultant for: Abbvie, BristolMyers Squibb, Gilead, Janssen, Eli Lilly, MSD, Novartis, Pfizer, RocheChugai, Sanofi, UCB

DOI: 10.1136/annrheumdis-2019-eular.2572

\section{FRI0156 A PHASE 1, SINGLE AND MULTIPLE ASCENDING DOSE STUDY OF TAS5315 - A NOVEL HIGHLY SELECTIVE INHIBITOR OF BRUTON'S TYROSINE KINASE-IN HEALTHY MALE VOLUNTEERS}

Yuji Kumagai ${ }^{1}$, Yoshiya Tanaka ${ }^{2}$, Mitsuru Murata ${ }^{3}$, Tsutomu Takeuchi ${ }^{3} .{ }^{1}$ Kitasato University School of Medicine, Kanagawa, Japan; ${ }^{2}$ University of Occupational and Environmental Health, Kitakyushu, Japan; ${ }^{3}$ Keio University School of Medicine, Keio University School of Medicine, Japan

Background: Bruton's tyrosine kinase (BTK) is expressed in the cells of the immune system and osteoclasts, and plays an important role in inflammation and bone resorption ${ }^{1}$. TAS5315 is a novel, highly selective inhibitor of BTK. In animal models, TAS5315 suppressed the inflammation at the joints and significantly suppressed extreme bone destruction, in a dose-dependent manner. It has the potential to become a treatment option in patients with rheumatoid arthritis (RA).

Objectives: To evaluate the safety, pharmacokinetics (PK), and pharmacodynamics (PD) of TAS5315 in healthy male volunteers.

Methods: The single ascending dose (SAD) study, which was the first-inhuman study, and the multiple ascending dose (MAD) study were conducted as randomized, double-blind, placebo-controlled and parallel-group comparative studies in a single center. In the SAD study, 70 subjects were enrolled and received $0.01-8 \mathrm{mg}$ of TAS5315 or placebo. In the MAD study, 31 subjects were enrolled and received 1-8 $\mathrm{mg}$ of TAS5315 or placebo once daily for 7 days. The allocation ratio (TAS5315: placebo) was 7:3 in the SAD study and 6:2 in the MAD study. The PD of TAS5315 was assessed by measuring the rate of BTK occupancy in peripheral blood mononuclear cells using a fluorescence probe. The expression level of CD203c in peripheral blood basophils treated with anti-lgE antibodies was also measured with a flow cytometer. The SAD and MAD studies were reviewed and approved by the IRB of Kitasato University Hospital.

Results: The observed PK profile of TAS5315 was linear in the dose range of $0.01-8 \mathrm{mg}$. TAS5315 was rapidly absorbed (median $\mathrm{T}_{\max }$ : $0.5-$ $1.5 \mathrm{hr}$ ) and eliminated (mean $\mathrm{T}_{1 / 2}: 1.00-1.37 \mathrm{hr}$ ). The maximum percentage of BTK occupancy by TAS5315 increased dose-dependently at $0.01-$ $2 \mathrm{mg}$ in SAD study. The occupancy rate of BTK peaked at $2 \mathrm{mg}$ and was almost $100 \%$ at $2-8 \mathrm{mg}, 6 \mathrm{hr}$ after administration and remained almost $80 \%$ or higher for up to $24 \mathrm{hr}$. The expression level of CD203c after basophil activation decreased by $80 \%$ at $2-8 \mathrm{mg}$ of TAS5315 $6 \mathrm{hr}$ after administration. No changes in the PD biomarkers were observed in the placebo group. The PD response was maintained after the reduction in the drug concentration. In the SAD and MAD studies, the incidence of adverse drug reactions (ADR) in the TAS5315 groups was $6.1 \%$ and $13.0 \%$, respectively. Two subjects $(8.7 \%)$ experienced subcutaneous hemorrhage in MAD study. No other ADR occurred twice in SAD and MAD studies. The severity of all ADR in SAD and MAD studies was mild and they were resolved without any treatment. There were no serious adverse events. None of the ADR showed a tendency towards a dose-dependent increase. The administration of TAS5315 resulted in a decrease in platelet aggregation and prolonged bleeding time. These changes returned to baseline level in the follow up measurement and there were no clinical safety concerns.

Conclusion: TAS5315 was tolerable when administered as repeated doses of up to $8 \mathrm{mg}$ once daily for 7 days. The inhibitory effect of BTK by TAS5315 was demonstrated and this provides the basis for an early Phase II study to evaluate the efficacy of TAS5315 in patients with RA.

\section{REFERENCE:}

[1] Drug Discov Today. 2014;19,1200-4.

Disclosure of Interests: Yuji Kumagai: None declared, Yoshiya Tanaka Grant/research support from: Abbvie, Astellas, Bristol-Myers Squibb, Chugai, Daiichi-Sankyo, Eisai, Mitsubishi-Tanabe, MSD, Ono, Taisho-Toyama, Takeda, Speakers bureau: Abbvie, Asahi-kasei, Astellas, Bristol-Myers Squibb, Chugai, Daiichi-Sankyo, Eli Lilly, Eisai, Glaxo-Smithkline, Janssen, Mitsubishi-Tanabe, Novartis, Pfizer Japan Inc, Sanofi, Takeda, UCB, YL Biologics, Mitsuru Murata Consultant for: Taiho Pharmaceutical Co., Ltd. Tsutomu Takeuchi Grant/research support from: Astellas Pharma Inc, Chugai Pharmaceutical Co, Ltd., Daiichi Sankyo Co., Ltd., Takeda Pharmaceutical Co., Ltd., AbbVie GK, Asahikasei Pharma Corp., Mitsubish Tanabe Pharma Co., Pfizer Japan Inc., Eisai Co., Ltd., AYUMI Pharmaceutical Corporation, Nipponkayaku Co. Ltd., Novartis Pharma K.K., Grant research support from: AbbVie, Asahi Kasei, Astellas, AstraZeneca AYUMI, Bristol-Myers Squibb, Chugai, Daiichi Sankyo, Eisai, Eli Lilly Japan, Janssen, Mitsubishi Tanabe, Nippon Kayaku, Novartis, Pfize Japan Inc, Taiho, Taisho Toyama, Takeda, Teijin, Grant/research support from: Astellas Pharma Inc., Bristol Myers Squibb, Chugai Pharmaceutical Co., Ltd., Mitsubishi Tanabe Pharma Co., Pfizer Japan Inc., Santen Pharmaceutical Co., Ltd., Takeda Pharmaceutical Co., Ltd., Teijin Pharma Ltd., AbbVie GK, Asahi Kasei Pharma Corp., Taisho Toyama Pharmaceutical Co., Ltd., SymBio Pharmaceuticals Ltd., Janssen Pharmaceutical K.K., Celltrion Inc., Nipponkayaku Co. Ltd., and UCB Japan, Consultant for: Astra Zeneca K.K., Eli Lilly Japan K.K., Novartis Pharma K.K., Mitsubishi Tanabe Pharma Co., Abbivie GK, Nipponkayaku Co.Ltd, Janssen Pharmaceutical K.K., Astellas Pharma Inc., Taiho Pharmaceutical Co. Ltd. Chugai Pharmaceutical Co. Ltd., Taisho Toyama Pharmaceutical Co. Ltd. GlaxoSmithKline K.K., UCB Japan Co. Ltd., Consultant for: AbbVie, Asah Kasei, Astellas, AstraZeneca, AYUMI, Bristol-Myers Squibb, Chugai, Daiichi Sankyo, Eisai, Eli Lilly Japan, Janssen, Mitsubishi Tanabe, Nippon Kayaku, Novartis, Pfizer Japan Inc, Taiho, Taisho Toyama, Takeda, Teijin, Consultant for: Astra Zeneca K.K., Eli Lilly Japan K.K., Novartis Pharma K.K., Mitsubishi Tanabe Pharma Co., Asahi Kasei Medical K.K., AbbVie GK, Daiichi Sankyo Co., Ltd., Bristol Myers Squibb, and Nipponkayaku Co. Ltd., Speakers bureau: Astellas Pharma Inc., Bristol Myers Squibb, Chugai Pharmaceutical Co., Ltd., Mitsubishi Tanabe Pharma Co., Pfizer Japan Inc., Santen Pharmaceutical Co., Ltd., Takeda Pharmaceutical Co., Ltd., Teijin Pharma Ltd., AbbVie GK, Asahi Kasei Pharma Corp., Taisho Toyama Pharmaceutical Co., Ltd., SymBio Pharmaceuticals Ltd., Janssen Pharmaceutical K.K., Celltrion Inc., Nipponkayaku Co. Ltd., and UCB Japan, Speakers bureau: AbbVie, Asahi Kasei, Astellas, AstraZeneca, AYUMI, Bristol-Myers Squibb, Chugai, Daiichi Sankyo, Eisai, Eli Lilly Japan, Janssen, Mitsubishi Tanabe, Nippon Kayaku, Novartis, Pfize Japan Inc, Taiho, Taisho Toyama, Takeda, Teijin, Speakers bureau: AbbVie GK., Bristol-Myers K.K., Chugai Pharmaceutical Co. Ltd., Mitsubishi Tanabe Pharma Co., Pfizer Japan Inc., Astellas Pharma Inc, Diaichi Sankyo Co. Ltd., Eisai Co. Ltd., Sanofi K.K., Teijin Pharma Ltd., Takeda Pharmaceutical Co. Ltd., Novartis Pharma K.K.

DOI: 10.1136/annrheumdis-2019-eular.1887

\section{FRI0157 OBSERVATIONAL STUDY OF HAIR FALL IN RHEUMATOID ARTHRITIS PATIENTS TREATED WITH LOW DOSE METHOTREXATE COMPARED TO HEALTHY CONTROLS}

Sharath Kumar, Dhivya Lokanath. Columbia Asia Referral Hospital Yeshwanthpur, Bangalore, Rheumatology, Bengaluru, India

Background: Chemotherapeutic drugs are known to cause of hair loss (typically anagen effluvium, starts at 2-4 weeks and most apparent at 1-2 months).(1) The effect of hair fall (or the perceived possibility of it) can be so distressing that up to $8 \%$ of patients may choose less effective chemotherapy regimens that do not cause hair loss.(2) Low dose methotrexate used in rheumatology has a different mode of action and side 